\title{
Role of Serotonin Hormone at Development of Diabetes Mellitus Type 2 disease
}

\author{
$\underline{\text { Authors }}$ \\ ${ }^{1}$ Dr.Mustafa Saleam Khalaf / AL-Rasheed University College / Iraq \\ ${ }^{2}$ Ali Hussein Mohammed Ali Al-Tameemi / Imamein kadhimein medical city / Iraq \\ ${ }^{3}$ Bahaa Burhanuldeen Kargule / College of Medical Sciences Techniques / University of \\ Mashreq / Iraq \\ E-mail : dr.mustafa_saleam@alrasheedcol.edu.iq
}

Mobile : 009647725503941

\begin{abstract}
Subject :Diabetes Mellitus (DM) type 2 is most common disease characterized by elevation of serum glucose level due to impair insulin production or impair cell response to insulin .Serotonin is hormonal neurotransmitter commonly found in brain cell but it also present in beta cells of pancreas. It is key hormone that stabilizes mood, feelings of well-being, and happiness .
\end{abstract}

Objective of the Study: Role of serotonin in development of DM type 2 disease .

Materials and Methods: This study was done on 30 patients with un-control DM type2 patients and 30 control DM type 2 patients, the all subjects age within this study were more than 50 years of both genders .After obtained serum, immediately used quantity method for measured level of serum serotonin concentration .

Results: This study shows reduce of serum serotonin concentration level in un-control DM type 2 group compare with control group .

Conclusion: This study confirms that decreased serum serotonin concentration level can act as support development of DM type 2 disease .

Keywords: serononin hormone and DM type 2 


\section{Introduction}

Diabetes Mellitus (DM) type 2 is most common disease at population characterized by glucose level increase in blood ,the age people more than 40 years are more suffers by it .The un-safecent of insulin hormone secretion by pancreas and human cells resistance to insulin are more causes of DM type 2 disease, that lead to hyperglycemia (1). Also , DM type 2 patients have many signs and symptoms for example frequent urination, dry skin and others. The hyperglycemia for long period can cause various complication such as diabetes nephropathy, retinopathy and others

Serotonin is hormone made from the essential amino acid tryptophan, this amino acid very important for body, therefore it must enter body through diet and is commonly found in foods such as nuts and red meat. It is key hormone that stabilizes mood, feelings of well-being, and happiness (3) . It enables brain cells and other nervous system cells to communicate with each other. However, if the brain has too little serotonin, it may lead to depression but If has too much serotonin, it can lead to excessive nerve cell activity (4) .

\section{Material and Methods}

The present research included selected 30 cases with un-control DM type 2 disease (group 1) and 30 healthy persons as control (group 2), age range of all individual was 50-60 years of both genders, this study done in The National Center for Diabetes - Iraq . This study measured serum level of serotonin hormones .

The collection of blood sample of all individuals were done via separation the blood sample immediately without any preservative factors to obtain pure serum for measurement of serotonin at P.M. period . This parameters was measured by ELISA technique (serial No. for serotonin

(ELISA kit SKU: SER39-K01, Eagle Biosciences company USA ).

Statistic analysis in current study was use the t-test method to show different in serotonin level between un-control DM type 2 group and 
control group. The t-test method used mean \pm standard deviation (SD) and $\mathrm{p}$-value ( $>0.05$ significant value) .

\section{Results}

This study compare between un-control DM type 2 group and control group by used serum serotonin hormone level .The study results shown significant deference between two groups according to serum serotonin hormone level .This study result presented reduce of serum serotonin level at un-control DM type 2 group when compare with control group. Shown table 1 .

Table 1: Comparison of serum serotonin hormone level between un-control DM type 2 and control groups according to Mean \pm Standard deviation (SD )by T-test statistic method

\begin{tabular}{|c|c|c|c|}
\hline Parameters & $\begin{array}{c}\text { Un-control DM type } \\
\text { 2 (NO. 30 } \\
\text { individuals) } \\
\text { Mean } \pm \text { SD }\end{array}$ & $\begin{array}{c}\text { Control (NO. 30 } \\
\text { individuals) } \\
\text { Mean } \pm \text { SD }\end{array}$ & P-value \\
\hline $\begin{array}{c}\text { Serotonin level } \\
(\mathrm{ng} / \mathrm{ml})\end{array}$ & $41.9 \pm 2.6$ & $74.2 \pm 5.8$ & $<0.05$ \\
\hline
\end{tabular}

\section{Discussion}

DM type 2 is chronic elevation of serum glucose level (hyperglycemia) caused by insulin hormone insufficient or insulin cells resistance of body. This condition can lead to many complications such as retinopathy, neuropathy and others. In present study results show significant reduce serum serotonin level at un-control DM type 2 group when compare with control group (5) .

Reduce of serotonin level at un-control DM type 2 group demonstrate that serotonin hormone have role in regulation of serum glucose level via insulin hormone regulation (6) . Serotonin is neurotransmitter commonly found in brain cell but it also present in beta cells of pancreas ,it made bond with enzymes. Insulin and serotonin before release storage in granules and release together. serotonin covalently bonds to the GTPase, a reaction called "serotonylation," which is catalyzed by a 
transglutaminase enzyme. Intriguingly, GTPases also help regulate insulin secretion in the pancreas (7) . This theory demonstrate in present study result, reduce of serotonin can lead to development of DM type 2 by decrease of insulin secretion. The present study result agree with Khoshnevisan K, Baharifar $\mathrm{H}$, and et al 2021 that also confirm reduce of serotonin level in DM type 2 patients (8) .

\section{Conclusion}

The current study conclude to reduce of serotonin hormone level at un-control DM type 2 patients lead to decrease of insulin secretion that lead to development of DM disease .

\section{References}

1- Ahlqvist E, Prasad RB, Groop L. Subtypes of type 2 diabetes determined from clinical parameters. Diabetes. 2020 Oct 1;69(10):208693.

2- Gu S, Wang X, Shi L, Sun Q, Hu X, Gu Y, Sun X, Dong H. Healthrelated quality of life of type 2 diabetes patients hospitalized for a diabetes-related complication. Quality of Life Research. 2020 Oct;29(10):2695-704.

3- Massabki I, Abi-Jaoude E. Selective serotonin reuptake inhibitor 'discontinuation syndrome'or withdrawal. The British Journal of Psychiatry. 2021 Mar;218(3):168-71.

4- Hassanlouei F, Behbudi Tabrizi L, Hosseini SA, Haj Rasoli M. The Effect of Running on Positive and Negative Slopes on Serotonin Levels in the Hippocampus Tissue of Rats with Alzheimer's Disease. Gene, Cell and Tissue. 2020 Jan 31;7(1).

5- Captieux M, Prigge R, Wild S, Guthrie B. Defining remission of type 2 diabetes in research studies: A systematic scoping review. PLoS medicine. 2020 Oct 28;17(10):e1003396. 
6- Field SL, Marrero MG, Dado-Senn B, Skibiel AL, Ramos PM, Scheffler TL, Laporta J. Peripheral serotonin regulates glucose and insulin metabolism in Holstein dairy calves. Domestic Animal Endocrinology. 2021 Jan 1;74:106519.

7- Paulmann N, Grohmann M, Voigt JP, Bert B, Vowinckel J, Bader M, Skelin M, Jevšek M, Fink H, Rupnik M, Walther DJ. Intracellular serotonin modulates insulin secretion from pancreatic $\beta$-cells by protein serotonylation. PLoS biology. 2009 Oct 27;7(10):e1000229.

8- Khoshnevisan K, Baharifar H, Torabi F, Afjeh MS, Maleki H, Honarvarfard E, Mohammadi H, Sajjadi-Jazi SM, Mahmoudi-Kohan S, Faridbod F, Larijani B. Serotonin level as a potent diabetes biomarker based on electrochemical sensing: a new approach in a zebra fish model. Analytical and bioanalytical chemistry. 2021 Mar;413(6):1615-27. 